\begin{tabular}{|c|l|}
\hline Title & $\begin{array}{l}\text { Integration of magnetism and heavy metal chemistry of soils to quantify the environmental pollution in Kathmandu, } \\
\text { Nepal }\end{array}$ \\
\hline Author(s) & Gautam, Pitambar; Blaha, U Irich; A ppel, Erwin \\
\hline Citation & $\begin{array}{l}\text { Island arc, 14(4), 424.435 } \\
\text { https://doi.org/10.1111’.1440-1738.2005.00496.x }\end{array}$ \\
\hline Issue Date & 2005-12 \\
\hline Doc URL & http://hdl.handle.net/2115/38429 \\
\hline Rights & The definitive version is available at www.blackwell-synergy.com \\
\hline Type & article (author version) \\
\hline File Information & gautam-3.pdf \\
\hline
\end{tabular}

Instructions for use 


\title{
Integration of magnetism and heavy metal chemistry of soils to quantify the environmental pollution in Kathmandu, Nepal
}

\author{
PitAmbar GAUTAM, ${ }^{1} *$ UlRich BlahA ${ }^{2}$ AND ERWIN APPEL ${ }^{2}$ \\ ${ }^{1}$ COE for Neo-science of Natural History, Graduate School of Science, Hokkaido University, \\ N10 W8, Sapporo 060-0810, Japan (e-mail: p-gautam@nature.sci.hokudai.ac.jp) and ${ }^{2}$ Institute \\ of Geosciences, University of Tübingen, Sigwartstrasse 10, D-72076 Tübingen, Germany
}

*Correspondence. Tel: +81 11706 4493, Fax: +81 117062986

\begin{abstract}
Soil profiles of Kathmandu urban area exhibit significant variations in magnetic susceptibility $(\chi)$ and saturation isothermal remanence (SIRM), which can be used to discriminate environmental pollution. $\chi$ can be used to delineate soil intervals by depth into normal $\left(<10^{-7} \mathrm{~m}^{3} \mathrm{~kg}^{-1}\right)$, moderately enhanced $\left(10^{-7}\right.$ to $\left.<10^{-6} \mathrm{~m}^{3} \mathrm{~kg}^{-1}\right)$ and highly enhanced $\left(\geq 10^{-6} \mathrm{~m}^{3} \mathrm{~kg}^{-1}\right)$. Soils far from road and industrial sites fall commonly into 'normal' category. Close to a road corridor, soils at several $\mathrm{cm}$ depth possess highest $\chi$, which remains high within the upper $20 \mathrm{~cm}$ interval, and decreases with depth through 'moderately magnetic' to 'normal' at $\sim 30-40 \mathrm{~cm}$. Soils in the upper parts profiles in urban recreational parks possess moderate $\chi$.

Soil SIRM has three components of distinct median acquisition fields $\left(\mathrm{B}_{1 / 2}\right)$ : soft $(30-50 \mathrm{mT}$ : magnetite-like phase), intermediate (120-180 mT: probably maghemite or soft coercivity hematite) and hard (550-600 mT: hematite). Close to the daylight surface, SIRM is dominated by soft component implying that urban pollution results in enrichment by magnetite-like phase.

Atomic absorption spectrometry of soils from several profiles for heavy metals (HM) reveals remarkable variability (ratio of maximum to minimum contents) of $\mathrm{Cu}$ (16.3), $\mathrm{Zn}$ (14.8) and $\mathrm{Pb}$ (9.3). At Rani Pokhari, several metals are well correlated with $\chi$ as shown by linear relationship between the logarithmic values. At Ratna Park, however, both $\chi$ and SIRM show significant positive correlation with $\mathrm{Zn}, \mathrm{Pb}$ and $\mathrm{Cu}$ but poor and even negative correlation with $\mathrm{Fe}(\mathrm{Mn}), \mathrm{Cr}$, $\mathrm{Ni}$ and Co. Such differences result from a variety of geogenic, pedogenic, biogenic and manmade factors, which vary in time and space. Nevertheless, for soil profiles affected by pollution (basically traffic-related), $\chi$ exhibits significant linear relationship with a pollution index based on the contents of some urban elements $(\mathrm{Cu}, \mathrm{Pb}, \mathrm{Zn})$, and therefore it serves as an effective parameter for quantifying the urban pollution.
\end{abstract}

Keywords: heavy metals, environmental pollution, Kathmandu, magnetic susceptibility, soil magnetism, isothermal remanence. 


\section{INTRODUCTION}

The Kathmandu Valley is situated within the Lesser Himalaya and is filled by fluvial and lacustrine sediments, of Plio-Pleistocene age, derived from the north and north-east and surrounding metasedimentary terrains (Yoshida \& Gautam 1988). The present state of environment of the Kathmandu valley has been deteriorating due to various causative factors such as the traffic pollution dominant in the urban area, industrial activities including the cement factory, emissions from the traditional brick-kilns scattered throughout the valley, biomass burning and others (Devkota 2001; Malinovsky 2001; Sharma et al. 2002). Hence, recognition of the major sources and types of the pollution, estimation of the share of each source, quantification of the degree of pollution, and monitoring are essential in order to reveal the spatial and temporal differences in pollution levels.

Following the effectiveness of integration of chemistry and magnetic properties in studies of the degree of pollution of the air, water, vegetation and land systems (Petrovsky \& Ellwood 1999; Knab et al. 2001; Hanesch \& Scholger 2002), we have already applied these properties to successfully characterize and quantify the degree of pollution in the Kathmandu urban area (Gautam et al. 2004, 2005). The variables measured in this respect are the various rockmagnetic properties (mass-specific magnetic susceptibility $(\chi)$, isothermal remanent magnetization (IRM), $\chi$ vs. temperature characteristics) of a variety of materials (dust-loaded leaves of road-side trees, road dust and soils from surface as well as vertical sections of up to several meters), and the contents of heavy metals (HM) in them.

In this paper, we describe $\chi$, IRM and its components, contents of $\mathrm{HM}(\mathrm{Cd}, \mathrm{Cu}, \mathrm{Co}, \mathrm{Cr}, \mathrm{Fe}$, $\mathrm{Mn}, \mathrm{Ni}, \mathrm{Pb}, \mathrm{Zn}$ ) and their relationship to $\chi$ and IRM in the urban and suburban soils in order to quantify the pollution levels. Emphasis is given to the use of the magnetic parameters as stand alone properties to characterize pollution and also as the effective proxy of contamination using an index that combines the contents of $\mathrm{Cu}, \mathrm{Pb}, \mathrm{Zn}$ which represent the urban elements (De Miguel et al., 1997). We collected soil samples from the following areas (Fig. 1): (i) the suburban background site in Kirtipur; (ii) the recreational areas and parks (Ratna Park, Rani Pokhari and exhibition ground) situated in the core urban areas; and (iii) the recreational park area in Balaju, which is close to an industrial area.

\section{RESEARCH METHODOLOGY}

The samples used in this study were collected during a field magnetic susceptibility survey in Kathmandu in February, 2002. Soils were taken either as cores of $3.5 \mathrm{~cm}$ diameter (obtained by vertically inserting a $30-\mathrm{cm}$ long hollow pipe into the ground) or as samples in $2.54 \mathrm{~cm}$ diameter (10 cc in volume) nonmagnetic containers obtained from walls of pits dug in situ. 


\section{MEASUREMENTS OF MAGNETIC PROPERTIES}

Standard (cylindrical with $2.54 \mathrm{~cm}$ diameter and $10 \mathrm{cc}$ volume) samples were measured for susceptibility using an AGICO KLY-2 Kappabridge, with an operating frequency of $920 \mathrm{~Hz}$ and sensitivity of $4 \times 10^{-8} \mathrm{SI}$, and normalized by the sample mass to obtain $\chi$.

IRM acquisition up to a maximum of $2.5 \mathrm{~T}$, using pulse fields at 18 to 20 steps generated by a Magnetic Measurements pulse magnetizer, was carried out on standard samples. The acquired IRM moment was measured by a Molspin spinner magnetometer. The IRM curves were analyzed using cumulative lognormal Gaussian decomposition techniques to discriminate the contribution of magnetic materials with differing coercivity spectra (Kruiver et al. 2001).

Variation of susceptibility with temperature $\left(40^{\circ} \mathrm{C}\right.$ to $\left.700^{\circ} \mathrm{C}\right)$ was recorded for soil, rock or cement specimens $\left(\sim 0.25 \mathrm{~cm}^{3}\right)$ using an AGICO KLY-3 Kappabridge, which operates at $875 \mathrm{~Hz}$ and has a sensitivity of $3 \times 10^{-8} \mathrm{SI}$, with an attached CS-3 furnace. Experiments were conducted in air and the measurement interval was $2.5^{\circ} \mathrm{C}$ with a heating rate of $10^{\circ} \mathrm{C} / \mathrm{min}$.

\section{CHEMICAL ANALYSIS}

For chemical analysis, 37 samples from various depth levels, chosen so as to represent the susceptibility variation along each selected soil profile, were taken from six soil profiles. The samples were oven-dried at $75^{\circ} \mathrm{C}$ for $48 \mathrm{hrs}$., homogenized and quartered and then about $1.8 \mathrm{~g}$ of each was digested by $8 \mathrm{ml}$ aqua regia (solution of conc. $\mathrm{HCl}$ and conc. $\mathrm{HNO}_{3}$ mixed at a ratio of 2:1) in a Kjeldatherm system (at $140^{\circ} \mathrm{C}, 2 \mathrm{hrs}$.). The solution was filtered and diluted by distilled water to get $250 \mathrm{ml}$ solution in a graduated flask. A Perkin-Elmer M1100 atomic absorption spectrophotometer of the Department of Geography, University of Tübingen was used to determine the contents of $\mathrm{Cd}, \mathrm{Cu}, \mathrm{Co}, \mathrm{Cr}, \mathrm{Mn}, \mathrm{Ni}, \mathrm{Pb}, \mathrm{Zn}$ and $\mathrm{Fe}$ using standard laboratory procedure.

\section{MAGNETIC PROPERTIES AND APPLICATION FOR SOIL PROFILE ZONATION}

\section{IRM CHARACTERISTICS}

IRM acquisition curves measured for representative soils from the background as well as urban areas and other possible constituents of urban soils (soot from diesel engine tailpipes, cements and brick fragments embedded into soils), are presented in Fig. 2. They exhibit complex shapes caused by the contributions from a number of components of differing magnetic coercivity. The difference in contribution of the soft coercivity components in group1 (soot and cement specimens), group2 (soils) and group3 (brick fragments) is clearly shown by the acquisition of $95-100 \%, 80-85 \%$ and $65-70 \%$ of the total remanence at $0.3 \mathrm{~T}$, respectively.

Modeling data for three specimens, one from each group, performed on IRM gradient data following Kruiver et al. (2001) are shown in Fig. 3. In general, three components are evident: soft (the median acquisition field $\left(\mathrm{B}_{1 / 2}\right)$ of $30-50 \mathrm{mT}$, intermediate $\left(\mathrm{B}_{1 / 2}=125-185 \mathrm{mT}\right)$, and hard $\left(\mathrm{B}_{1 / 2}=560-580 \mathrm{mT}\right)$, which are inferred to represent magnetite-like, maghemite-like phase (or possibly a soft coercivity hematite), and hematite phase, respectively. Inference of a maghemite-like phase for the intermediate coercivity is based on the close link of such phase to 
the $340-350^{\circ} \mathrm{C}$ decomposition temperatures seen in thermal variation of susceptibility discussed in Gautam et al. (2004). Alternatively, an interpretation of the intermediate coercivity phase in terms of a soft hematite is in line with the widely observed coercivity range $(28-769 \mathrm{mT})$ found in the published literature (Peters \& Dekkers 2003: Fig. 3 and Table 1). The magnetite-like phase found in soil and brick fragments has lower coercivity than that in the soot or cement material.

\section{THERMAL VARIATION OF THE MAGNETIC SUSCEPTIBILITY}

The heating curves for high-susceptibility soils (Hx3, Hx8), brick and cement specimens exhibit differing behavior (Fig. 4a,b). In broad terms, the urban soils exhibit the following characteristic features (Fig. 4a) indicative two magnetic phases: (i) a gradual, though not regular, increase of susceptibility between room temperature to $\sim 260-280^{\circ} \mathrm{C}$, attaining an enhancement peak $\left(\mathrm{e}_{1}\right)$; (ii) subsequent gradual decrease of susceptibility culminating at a minimum $\left(\mathrm{d}_{1}\right)$ within $\sim 400-$ $420^{\circ} \mathrm{C}$; (iii) further rapid increase of susceptibility resulting in a maximum enhancement peak $\mathrm{e}_{2}$ (at $\sim 510-530^{\circ} \mathrm{C}$ ); and (iv) a subsequent near complete susceptibility drop by $\sim 580-600^{\circ} \mathrm{C}\left(\mathrm{d}_{2}\right)$. The cooling curves (not shown here) for these soil samples showed significant susceptibility rise (the maximum susceptibility peaks were 2 to 5 times higher than the susceptibility measured before initial heating) and partial recovery of all the characteristic features. In analogy with the previous works on soil from Kathmandu (Gautam et al. 2004: Fig. 9), paleosols from China (Liu et al. 2005) and partially oxidized magnetite (Kosterov 2002), features (i) and (ii) may arise from gradual unblocking of fine-grained SD particles or annealing of some defects and/or internal stresses in magnetic particles and partial conversion of maghemite to magnetite and/or even hematite, respectively. In contrast, features (iii) and (iv) in the high-temperature range are inferred to be due to a magnetite-like phase, which in pure form would have yielded a Curie temperature of $580^{\circ} \mathrm{C}$ (Dunlop \& Özdemir 1997). The susceptibility enhancement $\left(\mathrm{e}_{2}\right)$ probably results in part from the neoformation of magnetite during heating (Liu et al. 2005).

In contrast, the brick and cement specimens are characterized by continued susceptibility enhancement (e) between room temperature and about $400-420^{\circ} \mathrm{C}$ and the following rapid drop (d) by $\sim 560-580^{\circ} \mathrm{C}$ indicating that a high-temperature magnetic phase predominates the magnetic mineralogy (Fig. 4b).

\section{MAGNETIC ZONATION OF VERTICAL SOIL PROFILES USING SUSCEPTIBILITY AND IRM DATA}

The presence of significant lateral and vertical magnetic susceptibility variations in the background sites as well as urban areas of the Kathmandu valley and application of susceptibility for mapping was described by Gautam et al. (2004). Here, we analyze $\chi$ and IRM magnitudes together with the percentage contribution of the components of differing coercivity spectra for vertical zonation of the urban soil profiles. Because of the ease, rapidity, and low- 
cost of measurements, $\chi$ alone is recommended for zonation using its magnitudes differing by factors of 10 (i.e., normal: $<10^{-7} \mathrm{~m}^{3} \mathrm{~kg}^{-1}$; moderately enhanced: $10^{-7}$ to $<10^{-6} \mathrm{~m}^{3} \mathrm{~kg}^{-1}$; and highly enhanced: $\left.\geq 10^{-6} \mathrm{~m}^{3} \mathrm{~kg}^{-1}\right)$. In addition, information on relative contribution of IRM components is useful in discerning the nature of magnetic minerals or phases which may be attributed to anthropogenic, geogenic/lithogenic, and pedogenic sources. Discrimination of the soil intervals is illustrated for two profiles in Fig. 5. In urban soil profiles, the relative contribution of the soft IRM component, commonly residing in magnetite-like phase, decreases with depth as does the degree of metallic pollution caused by anthropogenic factors (also described later). Gautam et al. (2004) described the derived nature of the soils, at least in the upper parts of the soil profiles, in the studied sites within the urban recreational parks and the systematic decrease of the in situ magnetic susceptibility with distance from road edges. Hence, the relative contribution of the anthropogenic or industrial sources to the susceptibility enhancement in the uppermost parts of soils is interpreted to be much higher than that arising from pedogenic processes leading to formation of magnetic minerals. Analysis of the susceptibility profiles in urban setting in Kathmandu suggests that the "normal" soil, in terms of the susceptibility enhancement attributable to the effect of pollution, commonly occurs below $30 \mathrm{~cm}$ depth (Fig. 3).

\section{RELATIONSHIP BETWEEN HM CONTENTS AND MAGNETIC PROPERTIES}

\section{HM CONTENTS IN SOILS}

Data on the HM contents and magnetic parameters ( $\chi$, SIRM and SIRM/ $\chi$ ratio) for discrete specimens collected from five vertical soil profiles (K: background site in Kirtipur; $\mathrm{Hx} 3, \mathrm{Hx} 7$, Hx 8 and Hx9 - from soils affected by urbanization) are presented in Table 1. As $\chi$ shows generally a strong grain-size dependency in samples with a complex assemblage of magnetic minerals, its magnitude alone may not be attributable to absolute enrichment of iron bearing materials. However, in case of the dominant contribution of magnetite (or maghemite) to susceptibility, as is the case in the upper parts of the urban soil profiles considered, the use of $\chi$ as a measure for the concentration of magnetic particles is theoretically justified (Heider et al. 1996). The interparametric ratio SIRM/ $\chi$ varies with grain size, concentration as well as mineralogy and therefore not easy to interpret even in the case of predominant magnetite/maghemite mineralogy. However, very low values of this ratio and SIRM are thought to reflect large paramagnetic contribution with negligible concentration of soft coercivity phases such as magnetite/maghemite (Table 1). Site K has the least variability of the magnetic properties as well the content of each heavy metal whereas the opposite can be said for site Hx8. The Cd contents are quite low $\left(<0.6 \mathrm{mg} \mathrm{kg}^{-1}\right)$ and below the detection limit in the majority of samples.

For relative interpretation, the measured HM data are listed together with the average contents found in the Earth's crust, uncontaminated soils and the sediments sampled from the Bagmati river in Kathmandu (Table 2). As the HM contamination in the soils considered is of anthropogenic nature, the possible sources for various elements are also summarized. Due to the 
obvious differences in magnitudes as well as variability of HM contents, the soils from Kirtipur and the urban soils from other sites have been considered separately.

The average values or at least the values at the lower end for the Kirtipur site are very close to the average contents for the uncontaminated soils with some exceptions for $\mathrm{Zn}$ and $\mathrm{Ni}$ characterized by clearly high values (Table 2). Both atmospheric deposition and agricultural practices might be the sources of these slightly elevated values for $\mathrm{Zn}$ and Ni. Nevertheless, the Kirtipur site can be regarded as the urban background site in terms of HM contents. Likewise, the lowest values commonly observed at greater depths (mostly below $30 \mathrm{~cm}$ ) in the urban soils are comparable to the average values in uncontaminated soils and may be regarded as local backgrounds. The contents of $\mathrm{Pb}$ and $\mathrm{Zn}$ in soils are generally lower than those in the Bagmati river sediments (Devkota 2001), whereas the opposite is true for $\mathrm{Cu}$.

Figure 6 gives an insight to the elemental variations with depth in the urban soil profiles. The soil along $\mathrm{Hx} 3$ has no distinct layering; it is basically silty soil with presence of relatively higher portion of sand in $12-22 \mathrm{~cm}$ and $33-43 \mathrm{~cm}$ intervals as well as occasional presence of clasts of bricks. The soil in $\mathrm{Hx} 7$ is also undifferentiated garden soil with predominantly silt sized particles. For profile $\mathrm{Hx} 3$, we see that elements $\mathrm{Cu}, \mathrm{Pb}$ and $\mathrm{Zn}$ behave differently from the others ( $\mathrm{Fe}, \mathrm{Cr}, \mathrm{Mn}, \mathrm{Ni})$. The elements in these two groups vary coherently with very good internal correlation. A common feature for both profiles is the abrupt decay of contents of HM, especially of $\mathrm{Cu}, \mathrm{Pb}$ and $\mathrm{Zn}$ approaching close to the local background levels at or below $\sim 25$ cm depth.

\section{HM CONTENTS VS. MAGNETIC SUSCEPTIBILITY}

Of the metals considered, $\mathrm{Cu}, \mathrm{Pb}$ and $\mathrm{Zn}$ are found to correlate well with susceptibility. This is exemplified by the $\mathrm{Pb}$ vs $\chi$ plot (Fig. 7). It is evident that $\mathrm{Pb}$ has good correlation with $\chi$ for each profile but with relationship that differs by locality obviously due to differences in the types of soils (Hanesch \& Scholger 2005). For example, Hx3 and Hx9 together fit into a line that passes through the mean value for the rather tightly clustered values for profile K. For profile $\mathrm{Hx} 8$, the data points are much scattered but still a positive correlation holds true.

\section{MAGNETIC PROPERTIES VS. POLLUTION LOAD INDEX}

Joint analysis of the soil profiles reveals that the contents of the urban elements $(\mathrm{Cu}, \mathrm{Pb}$ and $\mathrm{Zn})$ are correlated among themselves and also with $\chi$. In order to facilitate rapid characterization of soil section in terms of metallic contamination, we propose to combine the contents of the three elements into a single index called the Tomlinson pollution load index (PLI) (Angulo 1996; Chan et al. 2001) (Fig. 8). This index is calculated as the geometric mean of the concentration factors $\left(\mathrm{CF}_{\mathrm{i}} ; \mathrm{i}=1\right.$ to $\left.\mathrm{n}\right)$ of several metals, where $\mathrm{CF}_{\mathrm{i}}$ of $\mathrm{i}^{\text {th }}$ metal represents the ratio of the content of that metal $\left(\mathrm{C}_{\mathrm{i}}\right)$ in the sample analyzed to its content at a background site $\left(\mathrm{C}_{\mathrm{b}}\right)$ unaffected by pollution as follows: 


$$
\mathrm{PLI}=\sqrt[3]{\left(\mathrm{CF}_{\mathrm{Cu}} \times \mathrm{CF}_{\mathrm{Pb}} \times \mathrm{CF}_{\mathrm{Zn}}\right)} \text { where, } \mathrm{CF}_{\mathrm{i}(\mathrm{i}=\mathrm{Cu}, \mathrm{Pb} \text { or } \mathrm{Zn})}=\mathrm{C}_{\mathrm{i}} / \mathrm{C}_{\mathrm{b}}
$$

It represents the number of times by which the concentration of the urban elements in soil at particular horizon exceeds the background. In this paper, $\mathrm{C}_{\mathrm{b}}$ has been replaced by the minimum value $\left(\mathrm{C}_{\mathrm{i} \min }\right)$ generally observed at depths virtually untouched by urban pollution. The index allows comparison of several profiles and judgement on the relative degree of metallic contamination and accordingly the degree of urban pollution. It is obvious from Fig. 8 that the PLI variation correlates very well with susceptibility as well as SIRM magnitudes.

\section{DISCUSSION AND CONCLUSIONS}

Results of recent research on particulate matter $\left(\mathrm{PM}_{10}\right.$ - mass of particles with aerodynamic diameters below $10 \mu \mathrm{m}$ per unit volume), river sediments, dust-loaded leaves from road sides, road dust and soil samples allow us to qualify and quantify the urban pollution. Sharma et al. (2002) described high values $\left(1150-3837 \mu \mathrm{g} / \mathrm{m}^{3}\right)$ of the hourly mean $\mathrm{PM}_{10}$ levels, at $1.5 \mathrm{~m}$ height at 30 busy urban locations in the Kathmandu valley for the year 1999, and related them basically to the vehicular traffic (vehicle emissions and suspension of dust due to vehicle movement). Devkota (2001) found significant variations in $\mathrm{Cd}, \mathrm{Cu}, \mathrm{Pb}$, and $\mathrm{Zn}$ among the sediment samples of the Bagmati River (Table 2), along which the HM contents increase after entering the main urban area when tributaries carrying city wastes meet the trunk river. These facts relate the elevated input of metals into river to urbanization. Gautam et al. (2005) studied the heavy metal content in the dust-loaded leaves from trees at the Kathmandu roadsides with varying level of traffic movement, and found the following ranges: Fe $(0.08-1.3 \mathrm{wt} . \%)$, Mn (18.3-281.9 ppm), Zn (15.9-195.2 ppm), Cu (4.7-41.5 ppm), Pb (1.8-38.4 ppm), Ni (0.6$8.1 \mathrm{ppm}$ ), $\mathrm{Cr}(1.7-6.4 \mathrm{ppm}$ ), Co (up to $4.1 \mathrm{ppm}$ ) and $\mathrm{Cd}$ (up to $1.2 \mathrm{ppm}$ ). One of the notable features of leaf data was a significantly positive linear correlation of logarithmic $\chi$ with most of the heavy metals and a high degree of mutual correlation, with coefficient of determination $\left(\mathrm{R}^{2}\right)$ of $0.69-0.77$ among $\mathrm{Cu}, \mathrm{Pb}$ and $\mathrm{Zn}$ implying that both the magnetically soft minerals of anthropogenic origin and the urban elements arise predominantly from traffic pollution. In yet another pilot study (Gautam 2004, unpubl. data), the fine fraction $(<0.063 \mathrm{~mm})$ constituting the dust from the road surface in Babarmahal area of Kathmandu, was found to have much higher HM contents as follows: Fe (1.4-1.8 wt.\%), Mn (244.9-374.9 ppm), Zn (92.1-161.2 ppm), $\mathrm{Cu}(30.6-75.2 \mathrm{ppm}), \mathrm{Pb}(23.9-55.8 \mathrm{ppm}), \mathrm{Ni}(12.8-18.2 \mathrm{ppm}), \mathrm{Cr}(10.7-23.4 \mathrm{ppm}), \mathrm{Co}$ $(2.6-6.1 \mathrm{ppm})$ and $\mathrm{Cd}$ (up to $1.0 \mathrm{ppm}$ ) for which the contribution from the traffic-related source was obvious.

Joint analysis of $\chi$, SIRM, and the HM contents in soil profiles from Kathmandu presented above reveals that each of these quantities has a wide range of variation and could be a potential pollution indicator. For the soils studied, $\mathrm{Cu}, \mathrm{Pb}$ and $\mathrm{Zn}$ consistently correlate to $\chi$ as well as the SIRM magnitudes. In analogy with the results from leaves and road dusts, we associate these elevated HM contents to the degree of urbanization and traffic movement (motor vehicle 
emissions; abrasion of tyres, brake linings as well as road surface; cycling of dust in suspension due to vehicular movement) as known also from elsewhere (e.g., Wong 1996; De Miguel et al. 1997).

In the case of Kathmandu soils or similar situations, we recommend the use of magnetic susceptibility as widely as possible, for the sake of ease, rapidity and low-cost of the measurements, for both lateral and vertical zonation. As the quality of magnetic material will differ according to the soil type, the proximity to roads, the proximity to various point sources of pollution, the rate of dry and wet atmospheric deposition etc., additional information can be acquired through analysis of IRM acquisition curves. The correlation of $\chi$ with PLI (based on $\mathrm{Cu}$, $\mathrm{Pb}$, and $\mathrm{Zn}$ contents) is excellent at local level (Fig. 8b) implying that susceptibility actually serves as an effective proxy of the urban pollution. For effective use of susceptibility as a proxy of the degree of pollution in soils through the use of pollution load index and its translation to the metallic levels in a new urban area, however, it is desirable to have a reference database that includes information on soil types, parent material, the background susceptibility, the background contents of each metal in areas differing in geological/pedological conditions and also knowledge on the possible sources of contamination.

\section{ACKNOWLEDGMENTS}

The authors are grateful to Dr. Prakash C. Adhikari, Tribhuvan University, and the Environmental unit of the Kathmandu Municipality for support during field work. PG gratefully acknowledges a Georg Forster postdoctoral fellowship from the Alexander von Humboldt Foundation, Germany and also the PD Researcher position under the $21^{\text {st }}$ Century COE for Neo-Science of Natural History (Project leader: Hisatake Okada) at Hokkaido University. Advice on chemical analysis by Rolf K. Beck and critical remarks on the manuscript by M. Torii and R. Scholger are very much appreciated.

\section{REFERENCES}

Alloway B. J. (ed.) 1995. Heavy Metals in Soils. Blackie Academic \& Professional.

ANGULO E. 1996. The Tomlinson pollution load index applied to heavy metal 'Mussel-Watch' data: a useful index to assess coastal pollution. Science of the Total Environment 187, 19-56.

Chan L. S., NG S.L., Davis A.M., Yim W.W.S. \& YeUnG C.H. 2001. Magnetic properties and heavy-metal contents of contaminated seabed sediments of Penny's Bay, Hong Kong. Marine Pollution Bulletin 42(7), 569-83.

Devkota D. 2001. Total and extractable (mobilizable and mobile) heavy metals in the Bagmati river sediment of Kathmandu, Nepal. A Journal of the Environment 6 (7), 34-51.

De Miguel E., Llamas J.F., Chacón E., Berg T., Larssen S., Røyset O. \& Vadset M. 1997. Origin and patterns of distribution of trace elements in street dust: unleaded petrol and urban lead. Atmospheric Environment 31 (17), 2733-40.

DunLOP D.J. \& OzDEMIR Ö. 1997. Rock Magnetism: Fundamentals and Frontiers. Cambridge University Press, Cambridge, 573 pp. 
Gautam P., Blaha U., ApPel E. \& Neupane G. 2004. Environmental magnetic approach towards the quantification of pollution in Kathmandu urban area, Nepal. Physics and Chemistry of the Earth 29, 973-84.

Gautam P., Blaha U. \& APPEL, E. 2005. Magnetic susceptibility of dust-loaded leaves as a proxy of traffic-related heavy metal pollution in Kathmandu city, Nepal. Atmospheric Environment 39, 2201-11.

HANESCH M. \& SCHOlger R. 2002. Mapping of heavy metal loadings in soils by means of magnetic susceptibility measurements. Environmental Geology 42, 857-70.

HANESCH M. \& SCHOLgER R. 2005. The influence of soil type on the magnetic susceptibility measured throughout soil profiles. Geophysical Journal International 161, 50-6.

Heider F. ZitZELSBerger A. \& FABiAn K. 1996. Magnetic susceptibility and remanent coercive force in grown magnetite crystals from $0.1 \mu \mathrm{m}$ to $6 \mathrm{~mm}$. Physics of the Earth and Planetary Interiors 93, 239-56.

KOSTEROV A. 2002. Low-temperature magnetic hysteresis properties of partially oxidized amgnetite. Geophysical Journal International 149, 269-76.

KNAB M., APPEL E. \& HofFMANN V. 2001. Separation of the anthropogenic portion of heavy metal contents along a highway by means of magnetic susceptibility and fuzzy c-means cluster analysis. European Journal of Environmental and Engineering Geophysics 6, 12540.

KRUIVER P.K., DeKKERS M.J. \& HeSLOP D. 2001. Quantification of magnetic coercivity components by the analysis of acquisition curves of isothermal remanent magnetization. Earth and Planetary Science Letters 189, 269-76.

LiU Q. S., Deng C. L., YU Y. J. et al. 2005. Temperature dependence of magnetic susceptibility in an argon environment: implications for pedogenesis of Chines loess/paleosols. Geophysical Journal International 161, 102-12.

MaLinOVsKy M. 2001. Air quality management in Kathmandu Valley. A Journal of the Environment 6 (7), 50-7.

Peters C. \& DeKKERS M. J. 2003. Selected room temperature magnetic parameters as a function of mineralogy, concentration and grain size. Physics and Chemistry of the Earth 28, 659-67.

Petrovsky E. \& EllwoOd B.B. 1999. Magnetic monitoring of pollution of air, land and waters. In Maher B. A. and Thompson R. (eds.) Quaternary Climates, Environments and Magnetism, pp. 279-322, Cambridge University Press, Cambridge.

Sharma T., Rainey R.C., Neumann C. M. et al. 2002. Roadside particulate levels at 30 locations in the Kathmandu Valley, Nepal. International Journal of Environment and Pollution 17(4), 293-305.

Shrestha B. \& PRADHAN S. 2000. Kathmandu Valley GIS database, ICIMOD, Kathmandu.

WONG J.W.C. 1996. Heavy metal contents in vegetables and market garden soils in Hong Kong. Environmental Technology 17(4), 407-14.

YoshidA M. \& GAUTAM. P. 1988. Magnetostratigraphy of Plio-Pleistocene lacustrine deposits in the Kathmandu Valley, central Nepal. Proceedings of the Indian National Science Academy 3, 410-17. 


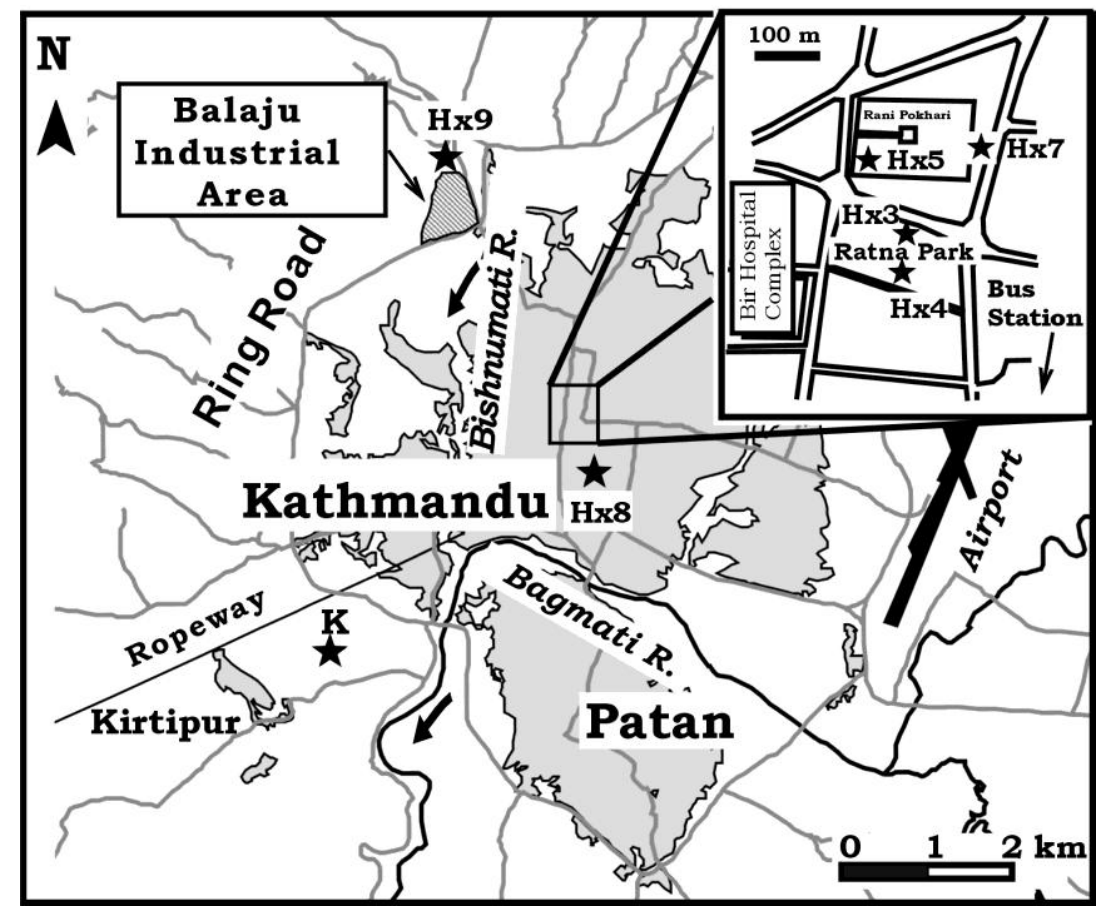

Fig. 1 Schematic map of the urban area (shaded) and its surroundings in the Kathmandu City in Nepal. Several soil coring sites (K: in suburban area near Kirtipur; Hx3-5 \& Hx7-8: in core urban area; and Hx9: close to the industrial area in Balaju), which are the objects of investigation for magnetic properties and heavy metal chemistry are indicated by stars. Background map after Shrestha \& Pradhan (2000). 


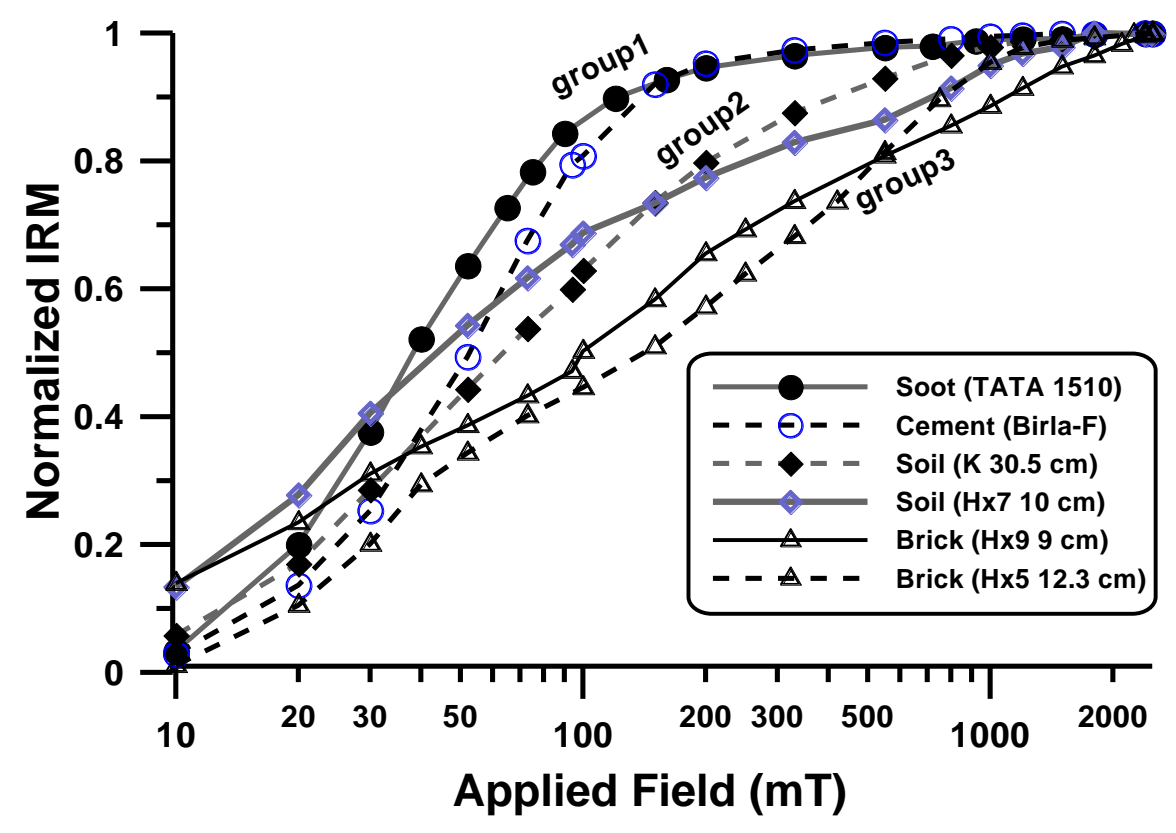

Fig. 2 IRM curves for representative samples showing 3 distinct appearances: group1 - sample of a cement (Birla Faizal, manufactured in India), used currently for construction of structures and the soot material (TATA 1510) extracted from the tailpipe of a Tata truck run on a diesel fuel; group 2 - soils from Kirtipur $(\mathrm{K})$ regarded as the urban background in pollution studies and urban center $(\mathrm{Hx} 7)$; and group3 - brick particles from urban soils $(\mathrm{Hx} 5, \mathrm{Hx} 9)$ at various depths. 


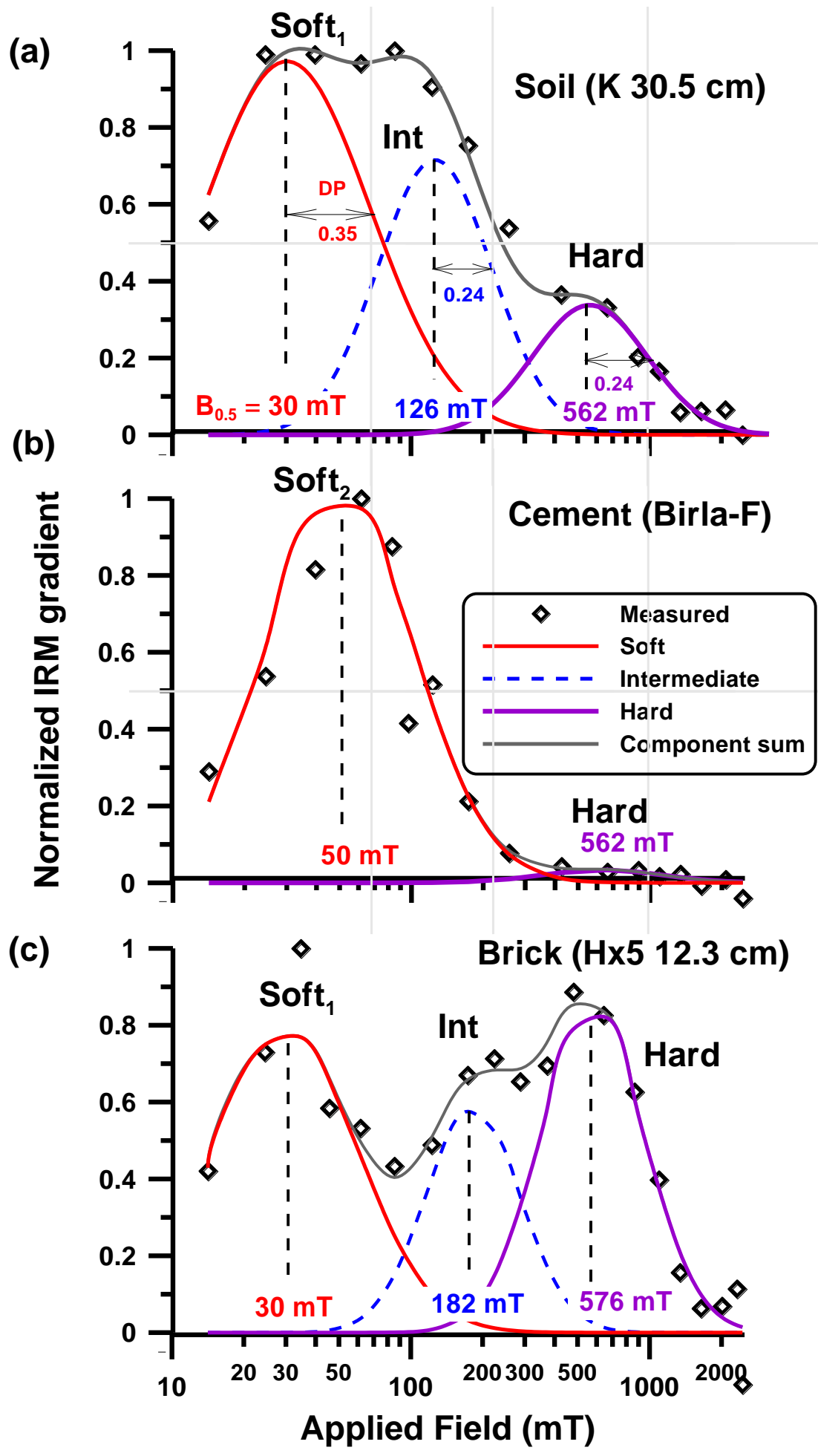

Fig. 3 IRM gradient analysis to discriminate the magnetic components differing in coercivity spectra. Following Kruiver et al. (2001), each component modeled can be characterized uniquely by two parameters: a median acquisition field $\left(\mathrm{B}_{1 / 2}\right)$ and a dispersion parameter (DP), both of which are illustrated for components contributing to the soil. 
(a)

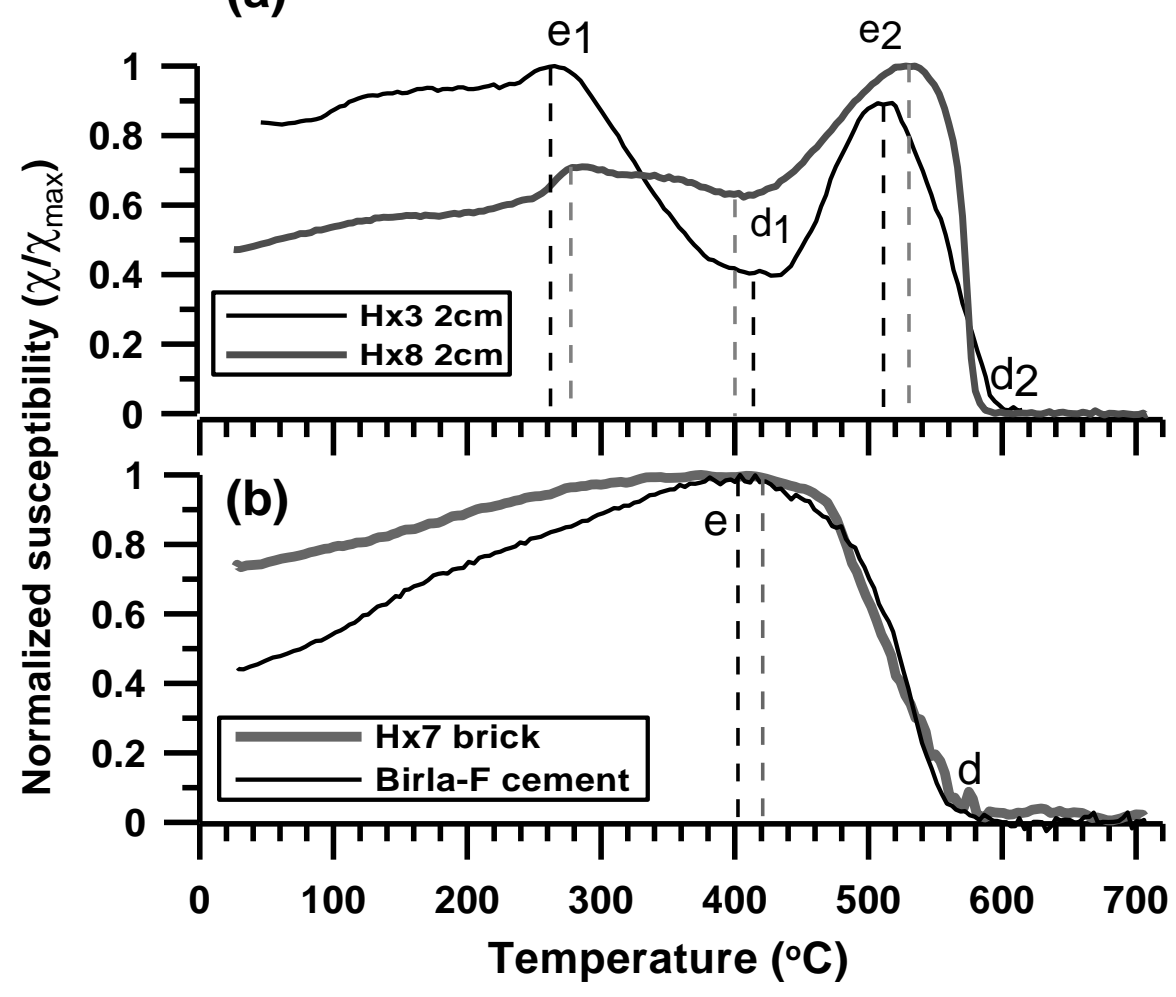

Fig. 4 Thermal variation of $\chi$ for urban soils (Hx3, Hx8), brick particle in soil (Hx7) and cement (Birla Faizal). Note the presence of at least two distinct magnetic phases in soil samples (a), as opposed to single phase in the brick and cement samples (b). The susceptibility enhancement peaks $\left(e, e_{1}, e_{2}\right)$ and drops $\left(d, d_{1}, d_{2}\right)$ are explained in the text. 
(a) Hx3: Ratna Park, N side

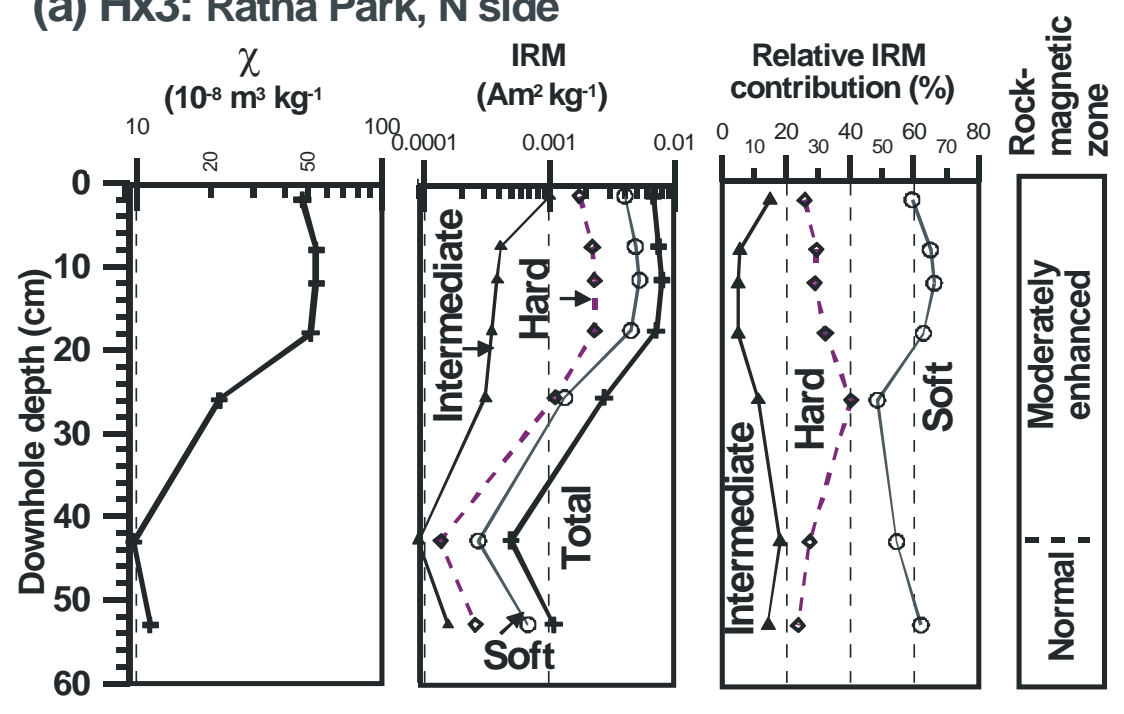

(b) Hx7: Rani Pokhari

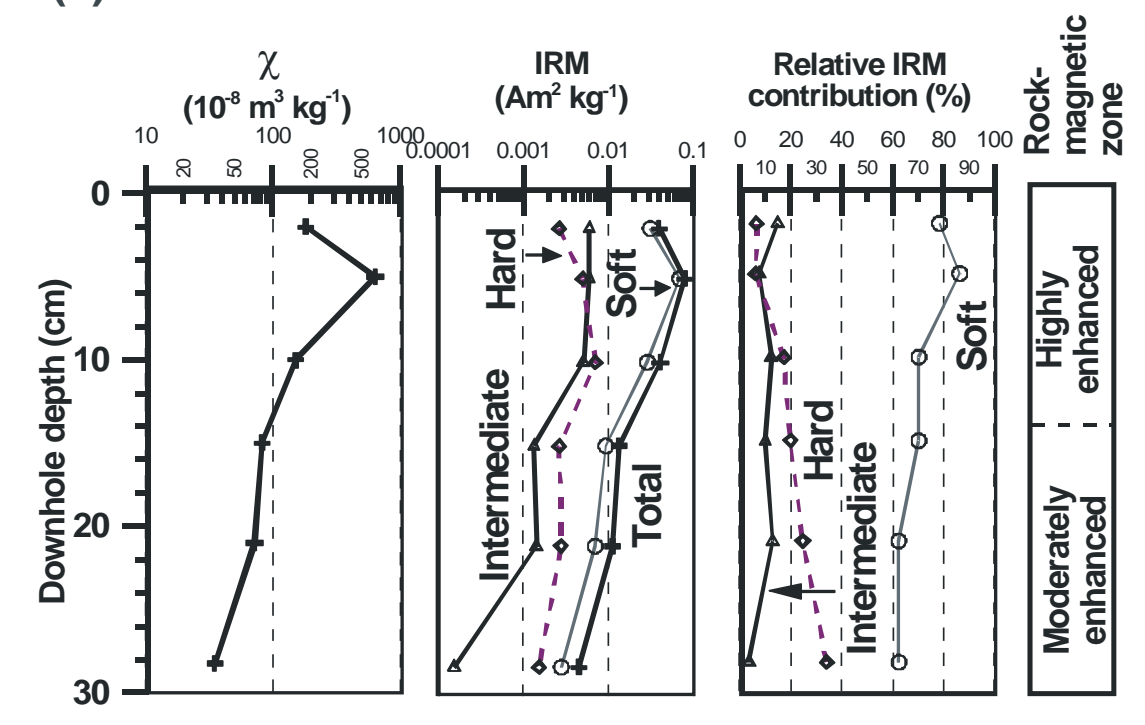

Fig. 5 Use of magnetic susceptibility $(\chi)$ and isothermal remanent magnetization (IRM) data for zonation and magnetic qualification of urban soils. Zonation is based on the magnitudes of $\chi$ (normal: $<10^{-7} \mathrm{~m}^{3} \mathrm{~kg}^{-1}$; moderately enhanced: $10^{-7}$ to $<10^{-6} \mathrm{~m}^{3} \mathrm{~kg}^{-1}$; and highly enhanced: $\geq 10^{-6} \mathrm{~m}^{3} \mathrm{~kg}^{-1}$ ) whereas the quality can be judged by the relative contribution of the IRM components of varying coercivity. The IRM components for each sample were estimated following Kruiver et al. (2001) as shown in Fig. 3. 


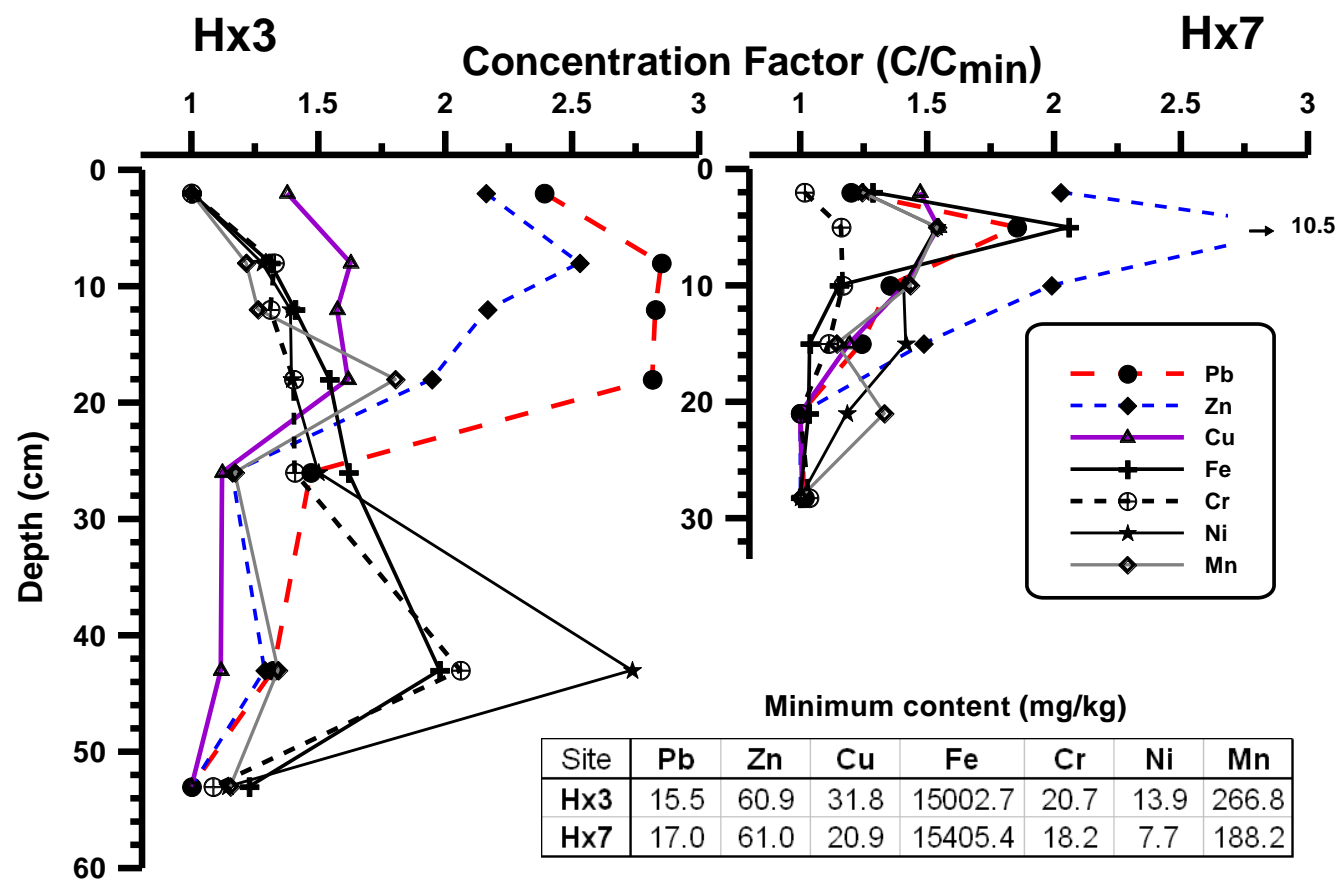

Fig. 6 Downhole variation of normalized heavy metal contents along two vertical soil profiles (Hx3: left, from Ratna park; and Hx7: right, from Rani Pokhari, eastern side) situated in the urban center. Note that some urban elements show maximum concentration within $10-20 \mathrm{~cm}$ leading to a remarkable decrease by about $25 \mathrm{~cm}$. 


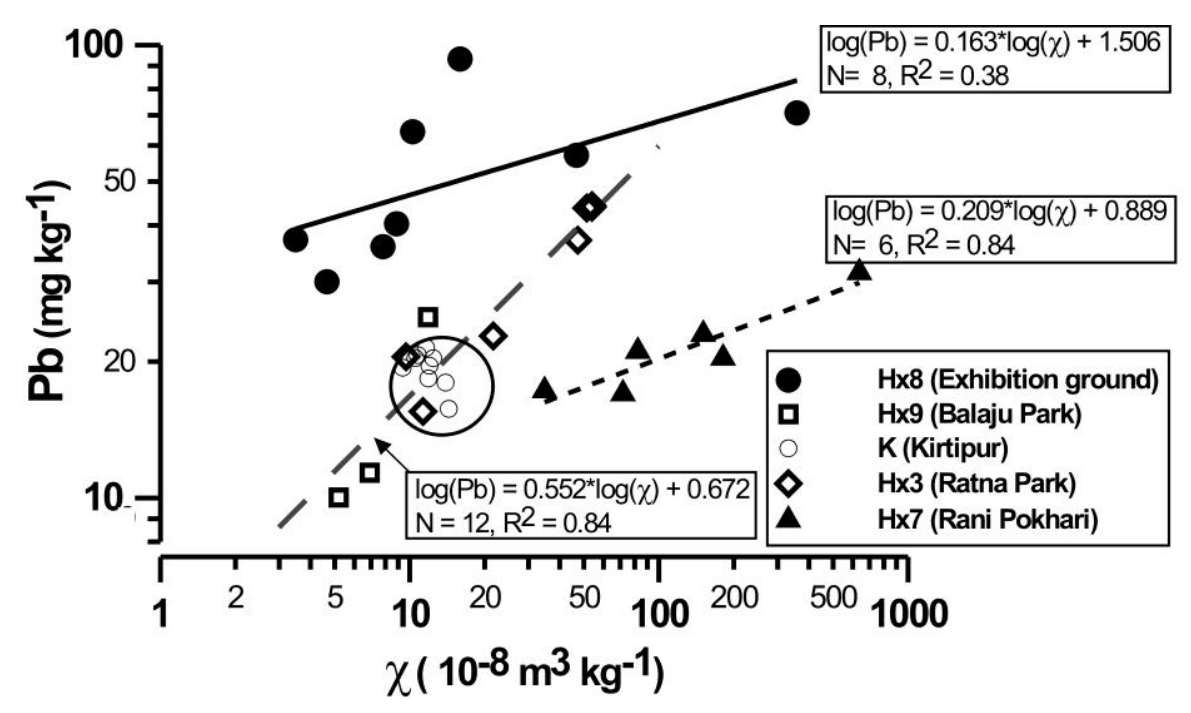

Fig. 7 Relationship between the contents of $\mathrm{Pb}$ in all soil samples against the mass-specific susceptibility. The least variability of both parameters characterizes the urban background site of Kirtipur (data points shown within the circle) whereas for other sites a reasonably linear, although variable dependence, between the logarithmic values may be noted. 


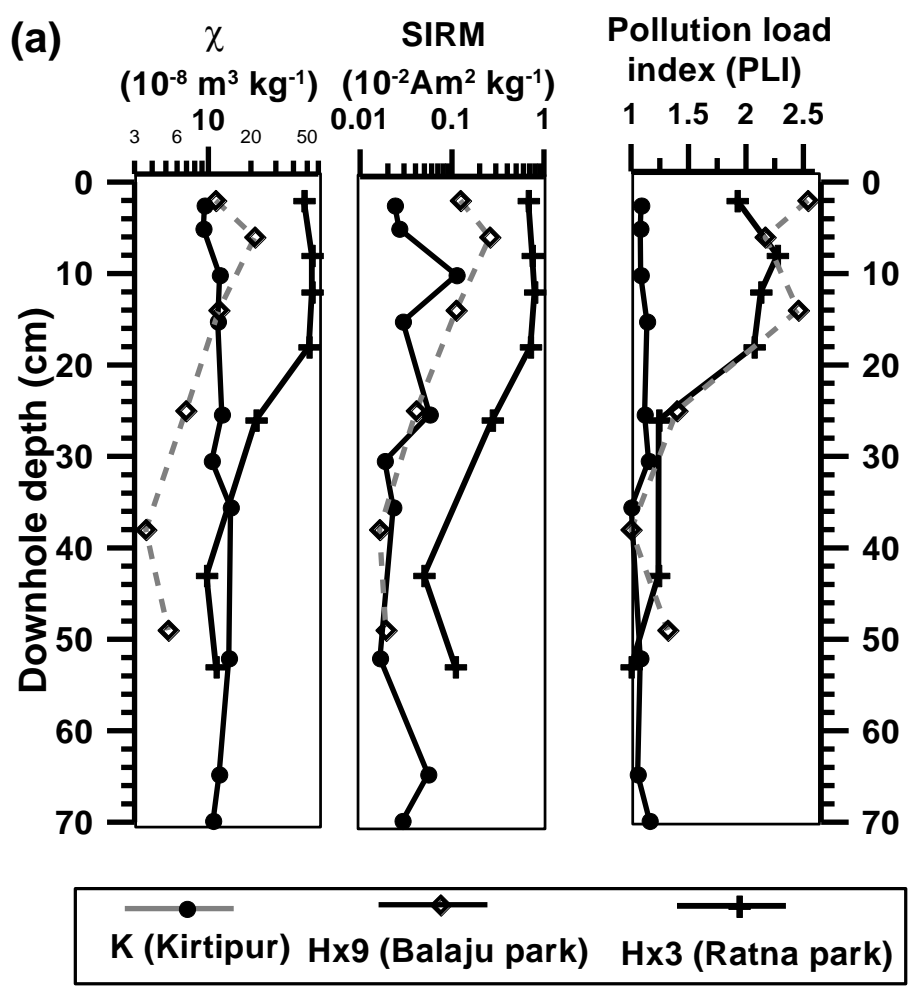

(b)

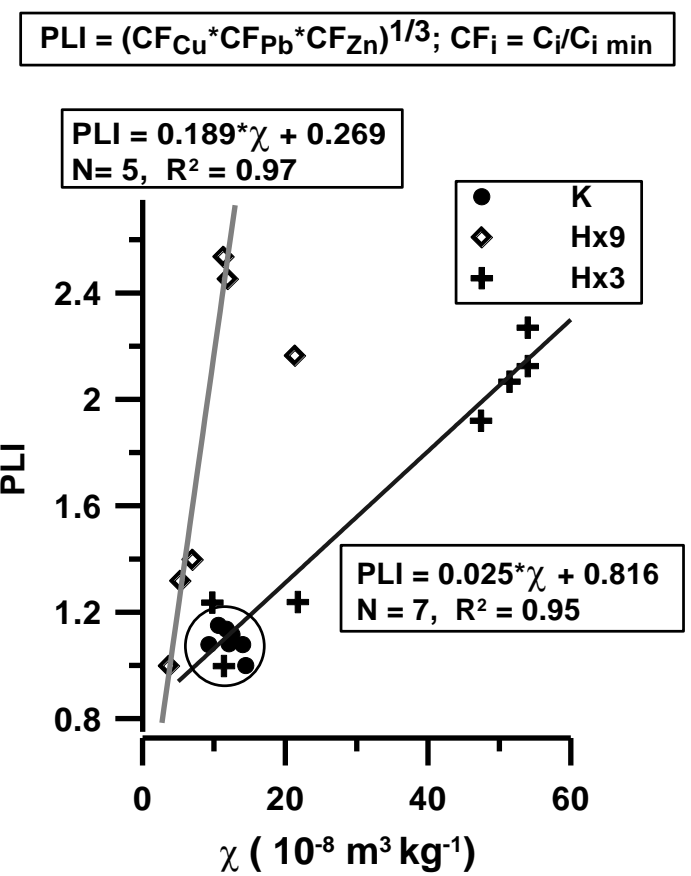

Fig. 8 (a) Comparison of the magnetic properties ( $\chi$, SIRM) and the pollution load index (PLI) based on the concentration factors $(\mathrm{CF})$ of 'urban elements' in three sites belonging to suburban $(\mathrm{K})$, industrial $(\mathrm{Hx} 9)$ and core urban $(\mathrm{Hx} 3)$ areas (see Fig. 1). (b) Cross-plot showing significant (coefficient of determination, $\mathrm{R}^{2} \geq 0.95$ ) linear correlation, although site-dependent, between PLI and $\chi$ justifying the use of the latter as a proxy of the pollution load. 
Table 1 Magnetic parameters and heavy metal contents of soil samples from Kathmandu

\begin{tabular}{|c|c|c|c|c|c|c|c|c|c|c|c|c|c|}
\hline \multirow[b]{2}{*}{ Site } & \multirow[b]{2}{*}{ Depth } & \multicolumn{3}{|c|}{ Magnetic parameters } & \multicolumn{9}{|c|}{ Heavy Metal contents (pseudo-total analysis, AAS ${ }^{* * *}$ ) } \\
\hline & & $\chi$ & SIRM & $\operatorname{SIRM} / \chi^{* *}$ & $\overline{\mathrm{Fe}}$ & $\overline{\mathrm{Mn}}$ & $\mathrm{Zn}$ & $\mathrm{Cu}$ & $\mathrm{Pb}$ & $\mathrm{Cr}$ & $\mathrm{Ni}$ & Co & $\mathrm{Cd}$ \\
\hline \multirow{11}{*}{ 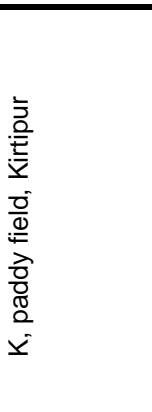 } & $(\mathrm{cm})$ & $\left(10-9 \mathrm{~m}^{3 / \mathrm{kg}}\right)$ & $\left(10^{-6} \mathrm{~A} \mathrm{~m}^{2} \mathrm{~kg}\right)$ & $\left(10^{3} \mathrm{~A} / \mathrm{m}\right)$ & \multicolumn{9}{|c|}{$(\%)(\mathrm{mg} / \mathrm{kg})(\mathrm{mg} / \mathrm{kg})(\mathrm{mg} / \mathrm{kg})(\mathrm{mg} / \mathrm{kg})(\mathrm{mg} / \mathrm{kg})(\mathrm{mg} / \mathrm{kg})(\mathrm{mg} / \mathrm{kg})(\mathrm{mg} / \mathrm{kg})$} \\
\hline & 2.5 & 93.8 & 238.0 & 2.5 & 3.4 & 441.6 & 85.5 & 35.4 & 19.4 & 34.0 & 33.5 & 12.8 & -0.5 \\
\hline & 5.1 & 92.0 & 265.6 & 2.9 & 3.2 & 409.3 & 84.6 & 35.4 & 19.2 & 33.5 & 32.9 & 13.8 & -0.1 \\
\hline & 10.2 & 120.2 & 1116.8 & 9.3 & 3.4 & 520.9 & 84.3 & 35.2 & 19.6 & 34.8 & 36.5 & 13.5 & 0.1 \\
\hline & 15.2 & 116.4 & 290.9 & 2.5 & 3.6 & 495.3 & 88.4 & 35.5 & 21.5 & 34.3 & 36.7 & 13.9 & 0.1 \\
\hline & 25.4 & 124.4 & 570.5 & 4.6 & 3.6 & 644.0 & 86.5 & 36.2 & 20.3 & 35.8 & 37.2 & 15.2 & 0.3 \\
\hline & 30.5 & 105.4 & 184.7 & 1.8 & 3.4 & 501.2 & 90.9 & 37.8 & 20.4 & 35.7 & 34.3 & 13.3 & -0.1 \\
\hline & 35.6 & 143.6 & 228.6 & 1.6 & 3.2 & 497.5 & 84.7 & 34.4 & 15.7 & 33.8 & 35.1 & 13.0 & 0.1 \\
\hline & 52.1 & 139.4 & 163.9 & 1.2 & 3.4 & 379.8 & 89.2 & 35.9 & 18.0 & 35.4 & 33.3 & 11.0 & -0.3 \\
\hline & 64.8 & 118.8 & 549.6 & 4.6 & 3.7 & 757.2 & 85.2 & 34.5 & 18.4 & 36.9 & 37.4 & 12.8 & -0.6 \\
\hline & 69.9 & 107.8 & 288.3 & 2.7 & 3.7 & 631.8 & 91.7 & 37.6 & 20.7 & 37.5 & 36.2 & 12.9 & -0.6 \\
\hline \multirow{7}{*}{ 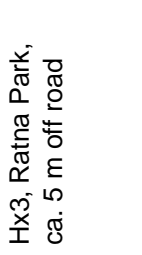 } & 2.0 & 473.3 & 6745.2 & 14.3 & 1.5 & 266.8 & 131.5 & 43.7 & 37.1 & 20.7 & 13.9 & 3.5 & 0.5 \\
\hline & 8.0 & 538.9 & 7450.5 & 13.8 & 2.0 & 324.2 & 154.0 & 51.7 & 44.2 & 27.5 & 17.8 & 7.9 & 0.6 \\
\hline & 12.0 & 538.8 & 7918.5 & 14.7 & 2.1 & 336.6 & 131.8 & 50.0 & 43.9 & 27.1 & 19.4 & 7.6 & 0.2 \\
\hline & 18.0 & 513.2 & 7124.5 & 13.9 & 2.3 & 481.1 & 118.5 & 51.4 & 43.7 & 29.1 & 19.4 & 8.9 & -0.2 \\
\hline & 26.0 & 216.6 & 2738.9 & 12.6 & 2.4 & 312.3 & 70.6 & 35.6 & 22.8 & 29.1 & 20.9 & 10.6 & -0.1 \\
\hline & 43.0 & 96.8 & 493.3 & 5.1 & 3.0 & 357.8 & 78.4 & 35.5 & 20.5 & 42.7 & 38.1 & 12.6 & -0.2 \\
\hline & 53.0 & 113.1 & 1084.3 & 9.6 & 1.8 & 307.5 & 60.9 & 31.8 & 15.5 & 22.5 & 15.9 & 8.2 & -0.1 \\
\hline \multirow{6}{*}{ 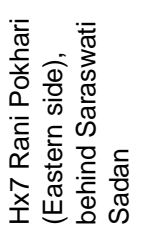 } & 2.0 & 1808.7 & 39738.2 & 22.0 & 2.0 & 233.9 & 123.5 & 30.8 & 20.4 & 18.5 & 9.6 & 5.6 & 0.0 \\
\hline & 5.0 & 6374.6 & 80102.0 & 12.6 & 3.2 & 289.7 & 636.6 & 32.3 & 31.5 & 21.1 & 11.8 & 5.5 & -0.6 \\
\hline & 10.0 & 1506.7 & 40979.1 & 27.2 & 1.8 & 269.6 & 121.3 & 29.5 & 23.0 & 21.2 & 10.8 & 5.3 & -0.2 \\
\hline & 15.0 & 822.8 & 13287.3 & 16.1 & 1.6 & 215.2 & 90.6 & 25.0 & 21.1 & 20.2 & 10.9 & 5.6 & -0.4 \\
\hline & 21.0 & 717.8 & 11195.8 & 15.6 & 1.6 & 250.5 & 61.0 & 20.9 & 17.0 & 18.2 & 9.1 & 6.5 & -0.4 \\
\hline & 28.3 & 348.1 & 4469.5 & 12.8 & 1.5 & 188.2 & 61.1 & 21.1 & 17.3 & 18.8 & 7.7 & 6.7 & -0.7 \\
\hline \multirow{8}{*}{ 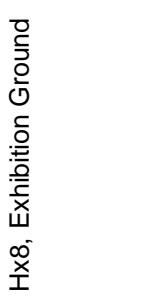 } & 2.0 & 3585.8 & 95673.8 & 26.7 & 3.9 & 490.8 & 184.2 & 165.5 & 70.9 & 29.5 & 15.1 & 10.9 & -1.3 \\
\hline & 12.0 & 467.1 & 11993.2 & 25.7 & 1.6 & 232.2 & 126.0 & 128.5 & 57.1 & 21.7 & 12.7 & 6.9 & 0.1 \\
\hline & 16.0 & 102.9 & 2980.2 & 29.0 & 1.8 & 379.4 & 142.1 & 162.7 & 64.4 & 22.4 & 15.1 & 11.1 & 0.2 \\
\hline & 22.0 & 159.3 & 3032.0 & 19.0 & 2.5 & 494.1 & 192.1 & 225.7 & 93.2 & 30.2 & 20.1 & 10.9 & 0.2 \\
\hline & 28.0 & 88.6 & 1453.2 & 16.4 & 1.4 & 197.1 & 89.4 & 133.1 & 40.3 & 19.6 & 13.0 & 8.9 & -0.2 \\
\hline & 37.0 & 78.2 & 1674.7 & 21.4 & 1.4 & 153.1 & 82.8 & 156.8 & 35.9 & 20.4 & 11.7 & 8.7 & 0.3 \\
\hline & 43.0 & 46.6 & 112.1 & 2.4 & 2.6 & 400.1 & 70.1 & 165.8 & 30.0 & 33.1 & 26.3 & 12.3 & -0.2 \\
\hline & 55.0 & 34.9 & 82.5 & 2.4 & 2.0 & 463.5 & 67.1 & 98.4 & 37.2 & 27.2 & 22.1 & 11.8 & 0.0 \\
\hline \multirow{6}{*}{ 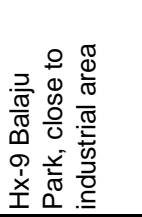 } & 2.0 & 112.5 & 1231.4 & 10.9 & 2.0 & 263.0 & 107.4 & 35.8 & 25.4 & 25.0 & 18.0 & 9.8 & 0.1 \\
\hline & 6.0 & 212.7 & 2575.0 & 12.1 & 1.6 & 234.6 & 104.2 & 31.6 & 18.4 & 22.2 & 12.3 & 6.3 & -0.1 \\
\hline & 14.0 & 118.5 & 1108.1 & 9.4 & 1.9 & 260.9 & 101.7 & 34.6 & 25.1 & 24.0 & 15.2 & 9.4 & -0.3 \\
\hline & 25.0 & 69.2 & 407.7 & 5.9 & 1.7 & 211.3 & 60.7 & 23.7 & 11.4 & 21.5 & 14.9 & 9.9 & 0.3 \\
\hline & 38.0 & 36.0 & 162.5 & 4.5 & 1.2 & 140.6 & 42.9 & 13.9 & 0.7 & 15.4 & 9.4 & 7.0 & 0.4 \\
\hline & 49.0 & 51.9 & 191.1 & 3.7 & 1.9 & 192.1 & 56.5 & 24.2 & 10.0 & 22.1 & 17.3 & 8.1 & 0.3 \\
\hline
\end{tabular}

** Very low $(<5 \mathrm{kA} / \mathrm{m}) \mathrm{SIRM} / \chi$ for $\mathrm{K}$ and the lower parts of $\mathrm{Hx} 8, \mathrm{Hx} 9$ point to large paramagnetic contribution

${ }^{* \star \star}$ AAS: atomic absorption spectrometry; Cd content in most samples is below detection limit and imprecise (e.g., negative) 
Table 2 Comparison of heavy metal contents in soils in the Earth's crust, uncontaminated soils around the world, and soils and sediments from Kathmandu.

$\frac{\begin{array}{c}\text { Average content } \\ (\mathrm{mg} / \mathrm{kg})[1]\end{array}}{\text { Un- }}$

Principal sources of metal contamination in urban/suburban soils [1]

Element Importance* [1] Earth's contaminate

\begin{tabular}{|c|c|c|c|c|c|c|c|}
\hline Elemen & Importance* $[1]$ & $\begin{array}{c}\text { Earth's } \\
\text { Crust }\end{array}$ & $\begin{array}{c}\text { contaminate } \\
\text { d Soils }\end{array}$ & 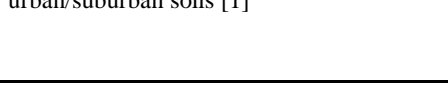 & $\begin{array}{l}\text { Paddy field, Kirtipur } \\
\qquad(\mathrm{N}=10)^{* *}\end{array}$ & $\begin{array}{l}\text { Urban soils } \\
(\mathrm{N}=27)\end{array}$ & $\begin{array}{c}\text { sediments }(\mathrm{N}= \\
12)[2]\end{array}$ \\
\hline $\mathrm{Cd}$ & $\begin{array}{l}\text { No essential } \\
\text { biologic } \\
\text { function. Toxic } \\
\text { at all levels }\end{array}$ & 0.1 & 0.53 & $\begin{array}{l}\text { Atmospheric deposition; incineration of } \\
\text { plastic containers \& batteries; sewage } \\
\text { sludge application to land; burning of fossil } \\
\text { fuels }\end{array}$ & $<0.3$ & $<0.6$ & $0.08-0.33$ \\
\hline $\mathrm{Co}$ & $\begin{array}{l}\text { Essential for } \\
\text { microorganisms } \\
\text { and ruminant } \\
\text { animals }\end{array}$ & 20 & $10-15$ & $\begin{array}{l}\text { Application of Co salts or Co-treated } \\
\text { phosphate fertilizers to topsoils }\end{array}$ & $13.2(11.0-15.2)$ & $3.5-12.6$ & n.a. \\
\hline $\mathrm{Cr}$ & $\begin{array}{l}\text { Essential for } \\
\text { animals }\end{array}$ & 100 & 40 & $\begin{array}{l}\text { Atmospheric deposition (production of } \\
\text { ferrochromes, refractory bricks and steel, } \\
\text { coal combustion, forest fires); disposal of } \\
\text { fly-ash; sewage sludge; ware of Cr- } \\
\text { containing asbestos brake linings; } \\
\text { application of fertilizers (phosphates), } \\
\text { limestones and manu }\end{array}$ & $35.2(33.5-37.5)$ & $15.4-42.7$ & n.a. \\
\hline $\mathrm{Cu}$ & $\begin{array}{l}\text { Essential for } \\
\text { animals and } \\
\text { plants }\end{array}$ & 50 & 30 & $\begin{array}{l}\text { Application of fungicides, fertilizers, } \\
\text { livestock manures, sewage sludge, fossil } \\
\text { fuel combustion }\end{array}$ & $35.8(34.4-37.8)$ & $13.9-225.7$ & $10.6-63.6$ \\
\hline $\mathrm{Mn}$ & $\begin{array}{l}\text { Essential for } \\
\text { animals, } \\
\text { microorganisms } \\
\text { and higher } \\
\text { plants }\end{array}$ & 950 & $20-500$ & $\begin{array}{l}\text { Application of } \mathrm{Mn} \text { (normally in the form of } \\
\mathrm{MnSO} 4, \mathrm{MnO} \text { or as an addition to } \\
\text { macronutrient fertilizers) to soils }\end{array}$ & $527.9(379.8-757.2)$ & $140.6-494.1$ & n.a. \\
\hline $\mathrm{Ni}$ & $\begin{array}{l}\text { Essential for } \\
\text { animals, some } \\
\text { microorganisms } \\
\text { and higher } \\
\text { plants }\end{array}$ & 80 & 23 & $\begin{array}{l}\text { Atmospheric deposition (burning of fuel } \\
\text { and residual oils, forest fires); diesel } \\
\text { exhaust; application of fertilizers } \\
\text { (phosphates), limestones and manures; } \\
\text { sewage sludge }\end{array}$ & $35.3(32.9-37.4)$ & $7.7-38.1$ & n.a. \\
\hline $\mathrm{Pb}$ & $\begin{array}{l}\text { No essential } \\
\text { biologic } \\
\text { function. } \\
\text { Poisonous for } \\
\text { mammals }\end{array}$ & 14 & 17 & $\begin{array}{l}\text { Application of manures \& sewage sludge; } \\
\text { vehicle exhausts; pesticides; atmospheric } \\
\text { deposition (vehicle fumes); abraded tyre } \\
\text { material, coal, plastics and rubber } \\
\text { factories, insecticides, car batteries, old } \\
\text { paint etc. }\end{array}$ & $19.3(15.7-21.5)$ & $10.0-93.2$ & $40.0-173.3$ \\
\hline $\mathrm{Zn}$ & $\begin{array}{l}\text { Essential for } \\
\text { humans, animals } \\
\text { and higher } \\
\text { plants }\end{array}$ & 75 & 50 & $\begin{array}{l}\text { Atmospheric deposition (the burning of } \\
\text { coal and fossil fuels), the smelting of non- } \\
\text { ferrous metals, sewage sludge, } \\
\text { agrochemicals (mineral and organic } \\
\text { fertilizers, soil amendments, pesticides etc. }\end{array}$ & $87.1(84.3-91.7)$ & $42.9-636.6$ & $60.3-277.0$ \\
\hline
\end{tabular}

* All elements but $\mathrm{Cd}$ and $\mathrm{Pb}$ are micronutrients that are essential (i.e. they are required for normal growth and their deficiency may lead to ab abnormality ) to certain levels. Their excessive contents, however, are toxic and poisonous.

[1] - Alloway (1995) - compiled from several papers in the edited volume; [2] - Devkota (2001). n.a. = not available.

** For site K, characterized by least variability of chemical contents, the mean values are accompanied by the min - max range within the brackets. 